\title{
Assessment of the cathode contribution to the degradation of anode-supported solid oxide fuel cells
}

\author{
Hagen, Anke; Liu, Yi-Lin; Barfod, Rasmus; Hendriksen, Peter Vang
}

Published in:

Journal of the Electrochemical Society

Link to article, DOI:

10.1149/1.2960938

Publication date:

2008

Document Version

Publisher's PDF, also known as Version of record

Link back to DTU Orbit

Citation (APA):

Hagen, A., Liu, Y-L., Barfod, R., \& Hendriksen, P. V. (2008). Assessment of the cathode contribution to the degradation of anode-supported solid oxide fuel cells. Journal of the Electrochemical Society, 155(10), B1047B1052. https://doi.org/10.1149/1.2960938

\section{General rights}

Copyright and moral rights for the publications made accessible in the public portal are retained by the authors and/or other copyright owners and it is a condition of accessing publications that users recognise and abide by the legal requirements associated with these rights.

- Users may download and print one copy of any publication from the public portal for the purpose of private study or research.

- You may not further distribute the material or use it for any profit-making activity or commercial gain

- You may freely distribute the URL identifying the publication in the public portal 


\title{
Assessment of the Cathode Contribution to the Degradation of Anode-Supported Solid Oxide Fuel Cells
}

\author{
A. Hagen, ${ }^{\text {a,z }}$ Y. L. Liu, ${ }^{a}$ R. Barfod, ${ }^{\text {b }}$ and P. V. Hendriksen ${ }^{\text {a }}$ \\ ${ }^{a}$ Fuel Cells and Solid State Chemistry Department, Ris $\phi$ National Laboratory, DK-4000 Roskilde, Denmark
}

${ }^{b}$ Topsoe Fuel Cell A/S, DK-2800 Lyngby, Denmark

The degradation of anode-supported cells was studied over $1500 \mathrm{~h}$ as a function of cell polarization either in air or oxygen on the cathode side. Based on impedance analysis, contributions of the anode and cathode to the increase of total resistance were assigned. Accordingly, the degradation rates of the cathode were strongly dependent on the $\mathrm{pO}_{2}$. Microstructural analysis of the cathode/electrolyte interface carried out after removal of the cathode showed craters on the electrolyte surface where the lanthanum strontium manganite (LSM) particles had been located. The changes of shape and size of these craters observed after testing correlated with the cell voltage degradation rates. The results can be interpreted in terms of element redistribution at the cathode/ electrolyte interface and formation of foreign phases giving rise to a weakening of local contact points of the LSM cathode and yttria-stabilized zirconia electrolyte and consequently a reduced three-phase boundary length (C) 2008 The Electrochemical Society. [DOI: 10.1149/1.2960938] All rights reserved.

Manuscript submitted January 30, 2008; revised manuscript received June 5, 2008. Published August 19, 2008.

Evaluation of the stability and understanding the degradation mechanisms of solid oxide fuel cells (SOFCs) have been challenges, both for industries and academia. Apart from determining the total degradation as a function of operating parameters, it is desirable to identify contributions from the individual cell components and the corresponding microstructural changes to be able to improve the stability of cells by focused materials and process development.

The degradation rate of anode-supported SOFCs is known to be a function of the testing temperature, current density, and polarization. ${ }^{1}$ Cathode degradation was identified to be the dominant contribution to degradation at low temperatures and high current densities. ${ }^{1}$ A significant difference in cathode degradation has been reported for cells when tested at $750{ }^{\circ} \mathrm{C}$ in oxygen or in air. ${ }^{2}$ Apart from an account of observed missing contact areas between the cathode and electrolyte after examination of cross sections of the cells after testing, the detailed degradation path on the cathode was not discussed in these studies.

The focus of the present paper is to discuss the degradation mechanisms of anode-supported SOFCs. A number of nominally identical cells were tested at $750^{\circ} \mathrm{C}$ over periods of $1500 \mathrm{~h}$ under different cathode atmospheres and current loads. Microstructural analysis in combination with detailed characterization by impedance spectroscopy is expected to contribute to a better understanding of the underlying degradation mechanisms, at the cathode/electrolyte interface in particular.

\section{Experimental}

SOFC.- Anode-supported SOFCs were studied. The supporting and active anode was a Ni-YSZ (yttria-stabilized zirconia) cermet, the electrolyte YSZ, and the cathode a lanthanum strontium manganite (LSM)-YSZ composite. The active area was $4 \times 4 \mathrm{~cm}^{2}$. The cells studied here were produced in the prepilot facility at Ris $\varnothing$ according to the same procedure as described in Ref. 3 .

Test equipment.- The tests were performed using alumina test houses with gold and nickel foil current collectors at the cathode and anode side, respectively. LSM and NiO/YSZ gas distribution components were used at the cathode and anode side, respectively. Sealing was accomplished using standard glass ceramics composite seals. ${ }^{4}$ The test setup and method are described in detail in Ref. 5. The cells were first heated in air to $1000^{\circ} \mathrm{C}$ with a heating rate of $1{ }^{\circ} \mathrm{C} / \mathrm{min}$ and a weight was applied to achieve sealing. Subsequently, the anode was reduced at this temperature in diluted $\left(9 \% \mathrm{H}_{2}\right.$ in nitrogen) followed by pure hydrogen, both humidified at room temperature.

${ }^{\mathrm{z}}$ E-mail: anke.hagen@ risoe.dk
Electrochemical characterization.- Prior to and after completion of the aging test, the cell characteristics ( $i V$ curves and impedance spectra: Solartron SI 1260 impedance analyzer) were recorded at 750 and $850^{\circ} \mathrm{C}$. Air was used as the cathode gas and hydrogen with 4 or $20 \%$ water vapor was applied on the anode side. In addition, impedance spectra were recorded under current load during aging tests.

Aging test.- The temperature was $750^{\circ} \mathrm{C}$ and the current loads 0.75 or $1.19 \mathrm{~A} / \mathrm{cm}^{2}$. The fuel gas was a mixture of $\mathrm{CO}_{2}$ and hydrogen with a ratio of 1 to 4 , yielding an equilibrium mixture of $\mathrm{CO}$, $\mathrm{H}_{2}$, and $\mathrm{H}_{2} \mathrm{O}$ corresponding to the product of methane reforming with a steam to carbon ratio of 2 . The fuel utilization was adjusted to lie between 75 and $85 \%$ and controlled by measuring the oxygen partial pressures at the fuel inlet and outlet. Compressed air, a mixture of nitrogen and oxygen, or 100\% oxygen were used as cathode gases. Specifically, the current loads were $0.75 \mathrm{~A} / \mathrm{cm}^{2}$ for two tests in air or oxygen and $1.19 \mathrm{~A} / \mathrm{cm}^{2}$ for one test in oxygen. The high current load in the test with oxygen was chosen to achieve the same initial cell voltage as for the test in air.

Microstructural analysis. - The microstructure analysis was focused on the cathode/electrolyte interface using a field-emission gun-scanning electron microscope (SEM) Supra-35 (sample not coated, accelerating voltage $2 \mathrm{kV}$, in-lens secondary detector). The cathode layer was removed by treatment of the cell in concentrated hydrochloric acid in an ultrasonic bath at room temperature for $10 \mathrm{~min}$. Subsequently, the sample was cleaned in water and ethanol. YSZ and (potentially formed) $\mathrm{La}_{2} \mathrm{Zr}_{2} \mathrm{O}_{7}$ (LZO) were stable in $\mathrm{HCl}$, whereas LSM was dissolved. To identify possible reaction products in the interface region, various energy-dispersive spectroscopy (EDS) techniques (point analysis and linescan) with high or low accelerating voltage were used.

\section{Results and Discussion}

Long-term stability in air and oxygen.- Impedance spectroscopy is a valuable tool to deconvolute the total resistance of a cell into contributions from the single components. Previously, a model was established assigning resistance contributions to cathode and anode processes based on detailed impedance studies carried out under open-circuit voltage (OCV) conditions. ${ }^{67}$ According to this model, cathode processes are reflected in a high- and a low-frequency arc $\left[\sim 12,000(\mathrm{HF})\right.$ and $\sim 150(\mathrm{LF}) \mathrm{Hz}$ at $750^{\circ} \mathrm{C}$, respectively], whereas anode contributions appear in between these two at around $1500-3000 \mathrm{~Hz}$. In addition, there is a low-frequency term from the anode due to conversion and diffusion. ${ }^{7}$ In Table I, the resistance contributions obtained for two of the cells before long-term testing are summarized. It can be seen that the performances, expressed as serial and polarization resistances from the anode and cathode, were the same. 


Table I. Resistance contributions derived from impedance spec-
tra recorded at $\mathbf{7 5 0}^{\circ} \mathbf{C}$ before test.
\begin{tabular}{lcccc}
$R_{\mathrm{s}}$ & $R_{\mathrm{p}}($ anode $)$ & $R_{\mathrm{p}}($ cathode- & $R_{\mathrm{p}}($ cathode- \\
To be tested in & $\left(\Omega \mathrm{cm}^{2}\right)$ & $\left(\Omega \mathrm{cm}^{2}\right)$ & $\mathrm{HF})\left(\Omega \mathrm{cm}^{2}\right)$ & $\mathrm{LF})\left(\Omega \mathrm{cm}^{2}\right)$ \\
\hline $\mathrm{O}_{2}\left(0.75 \mathrm{~A} / \mathrm{cm}^{2}\right)$ & 0.10 & 0.15 & 0.10 & 0.12 \\
$\mathrm{Air}\left(0.75 \mathrm{~A} / \mathrm{cm}^{2}\right)$ & 0.12 & 0.15 & 0.10 & 0.11
\end{tabular}

For the aging tests, severe operating conditions were applied, harsher than required for most potential technological applications. This approach was chosen because the SOFCs did not show significant degradation under milder, technologically more relevant, conditions, whereas the aim of this study required a large degradation effect.

The degradation behaviors in air and oxygen at $0.75 \mathrm{~A} / \mathrm{cm}^{2}$ were remarkably different (see Fig. 1). The cell voltage decreased continuously in the test in air, whereas it dropped fast initially during the test in oxygen at the same current load and remained nearly constant afterward over the whole period of $1500 \mathrm{~h}$. Evidently, a pronounced degradation mechanism occurring in air does not occur in oxygen.

To assess the mechanism behind the degradation, it might be important to establish whether the observed difference was a consequence of the different cell (and thus cathode) polarization or the different oxygen activity. A current density of $1.19 \mathrm{~A} / \mathrm{cm}^{2}$ was therefore applied in a test with pure oxygen to investigate the effect of high cathode polarization under the conditions of high oxygen activity in the cathode/electrolyte interface region/the absence of oxygen concentration gradients on the degradation behavior (see Fig. 1). The specific current density of $1.19 \mathrm{~A} / \mathrm{cm}^{2}$ was chosen to achieve the same initial cell voltage for the test in oxygen as for the test in air (see Fig. 1 and Table II). Applying the same high current density for a test in air would lead to a cell voltage near or below 450-500 mV.

The cell polarizations $\left[\eta_{\text {cell }}=\right.$ electromotive force $(\mathrm{emf})$ $-U]$ are listed in Table II. The total cell polarization of the cell tested in oxygen at a high current load $\left(1.19 \mathrm{~A} / \mathrm{cm}^{2}\right)$ was similar to that of the cell tested in air at $0.75 \mathrm{~A} / \mathrm{cm}^{2}$. During the aging test, two unintended interruptions of the current/gas supply occurred, where the cell was set to OCV and under a diluted hydrogen gas mixture (see the breaks in the cell voltage curve in Fig. 1). After these interruptions, the initial cell voltage was not completely recovered when returning to the aging test. However, the general cell voltage degradation trend was the same as during the test in oxygen at a

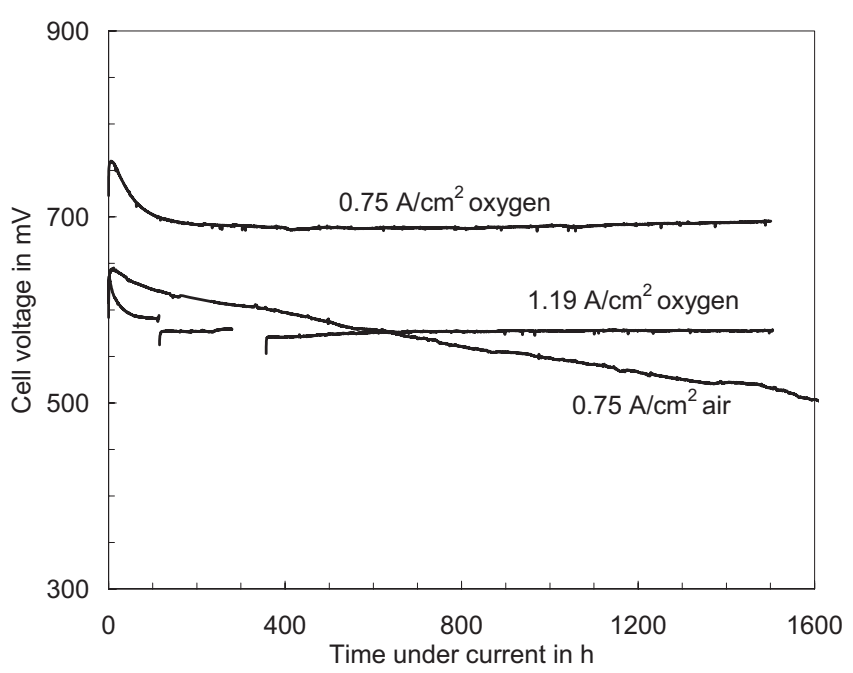

Figure 1. Cell voltage vs time under current for tests in air or oxygen at $750^{\circ} \mathrm{C}$ and 0.75 or $1.19 \mathrm{~A} / \mathrm{cm}^{2}$.

\begin{tabular}{|c|c|c|}
\hline Test in & $I\left(\mathrm{~A} / \mathrm{cm}^{2}\right)$ & $\eta_{\text {cell }}=\operatorname{emf}-U(\mathrm{mV})$ \\
\hline Oxygen & 0.75 & 260 \\
\hline Oxygen & 1.19 & 410 \\
\hline Air & 0.75 & 400 \\
\hline
\end{tabular}

lower polarization. A fast initial drop of the cell voltage was followed by a period at constant value, despite the higher cell and also cathode polarization.

The improved stability in oxygen comparing the two tests at $0.75 \mathrm{~A} / \mathrm{cm}^{2}$ was thus not due to a reduced polarization. It rather seems to be related with the increased oxygen activity in the cathode/electrolyte interface or the absence of oxygen gradients.

Other factors affecting the degradation apart from oxygen activities and polarization could be impurities in the compressed air (such as humidity, which was measured to be only $<0.1 \%$ in the compressed air though), which were absent in the oxygen used in the respective test. To obtain a better comparison between oxygen and air, other long-term tests were performed using synthetic air (a mixture of nitrogen and oxygen in the ratios $5 / 1$ and $4 / 1$; gases were as dry as under test in oxygen) under otherwise identical conditions $\left(750^{\circ} \mathrm{C}, 0.75 \mathrm{~A} / \mathrm{cm}^{2}\right.$, synthesis gas on the anode). In Fig. 2 , the degradation in terms of increase of area specific resistance ( $\triangle \mathrm{ASR})$ is shown for the tests in compressed air and in the nitrogen/oxygen mixtures and in oxygen. Indeed, the degradation rates were smaller in the tests with synthetically mixed compared to compressed air. Moreover, the degradation was slightly smaller in the test with a higher oxygen content in the $\mathrm{O}_{2} / \mathrm{N}_{2}$ mixture. However, the pattern, i.e., the continuous increase (in contrast to a sharp initial change followed by a constant period) was the same as observed for the test in compressed air. A significant degradation effect related to the oxygen activity can thus be concluded. To identify the origin of the difference of degradation rates when testing in compressed air compared to synthetic air, more testing and analysis of the gas compositions is necessary. Humidity traces might have an effect or other constituents or impurities, but this is only speculation at this point.

The cells were characterized by impedance spectroscopy after completion of the long-term aging and the impedance compared to the values prior to the long-term testing (see Fig. 3). The impedance spectra were fitted to five arcs using the model presented in Ref. 7. In this model, three arcs in the high-frequency region were assigned to electrode polarization resistances; more specifically, two of them were related to the cathode and one in between these to anoderelated processes.

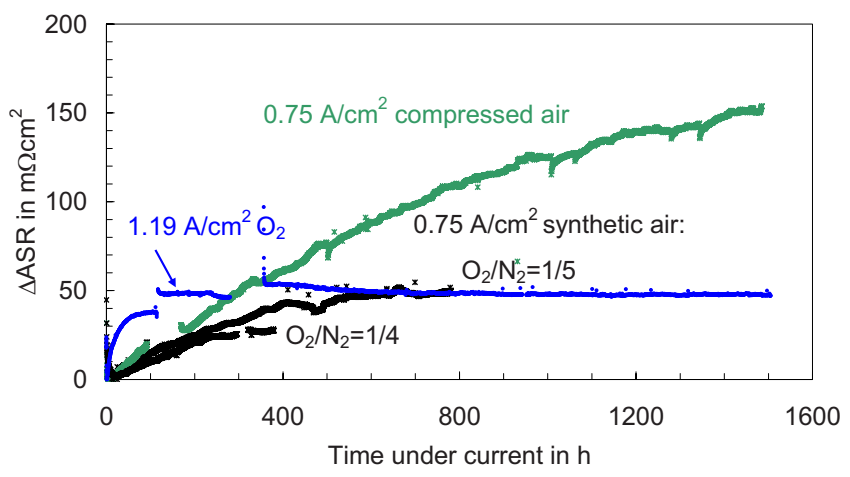

Figure 2. (Color online) Change of ASR ( $\triangle \mathrm{ASR}$ : initial ASR was set to zero for better comparison between the tests) vs time under current for tests in compressed or synthetically mixed air (oxygen and nitrogen: $1 / 5$ and 1/4) at $0.75 \mathrm{~A} / \mathrm{cm}^{2}$ or in oxygen at $1.19 \mathrm{~A} / \mathrm{cm}^{2}$, all tests at $750^{\circ} \mathrm{C}$. 


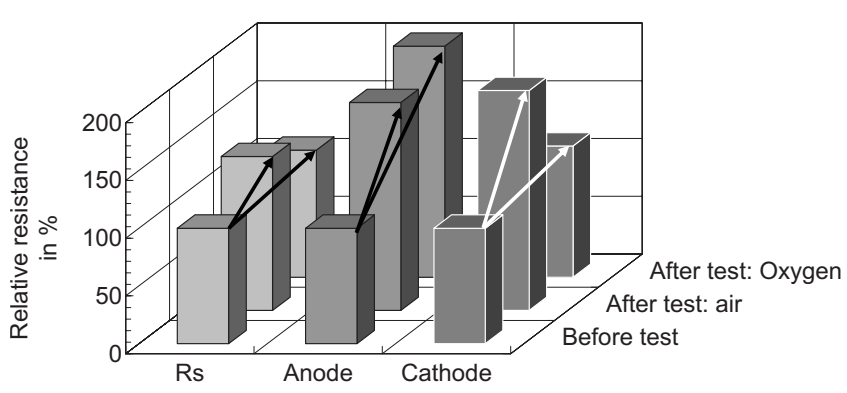

Figure 3. Relative ASR contributions deduced from impedance spectra recorded at $750^{\circ} \mathrm{C}$ for the cells tested in air or oxygen at $0.75 \mathrm{~A} / \mathrm{cm}^{2}$ prior to and after testing.

The serial resistance increased after testing in air but remained constant after testing in oxygen. The resistance contributions assigned to anode processes increased after both tests, to a slightly larger extent after testing in oxygen compared to air. A significant difference was observed for the cathode-related resistances (both high- and low-frequency contributions). After testing in air, the cathode resistance almost doubled, whereas it increased only slightly (by $15 \%)$ after testing in oxygen. In combination with the degradation of the cell voltage over time, these findings suggest a strong suppression of the cathode degradation when testing the cell in oxygen compared to air. Furthermore, the anode degradation seems to occur over the first few hundred hours of testing, preferentially (see also Fig. 1).

Impedance analysis before and after testing can deliver valuable information about the state of the cell and those parts that were mainly affected by the test. However, it is also of interest to follow resistance changes directly during uninterrupted testing by means of impedance spectroscopy under current load, when the cell is in an "active" state.

During a number of long-term tests, impedance spectra were recorded under current load. In the initial first $\sim 24 \mathrm{~h}$ of testing, a decrease of the resistance (activation) has been reported, which has been attributed to LSM cathode activation processes under polarization. ${ }^{8,9}$ Afterward, the resistances increased as a consequence of degradation. In Fig. 4, impedance spectra obtained under current during tests in air or oxygen are shown after selected periods of testing.

In the impedance spectra of a test in air, the serial resistance increased continuously over the whole period, in addition, the polarization resistance increased (see Fig. 4a). This behavior was confirmed for a number of cells of the same type tested under the same conditions. Remarkably different was the behavior in oxygen. The serial resistance remained constant over the whole $1500 \mathrm{~h}$ of testing. The polarization resistance increased only slightly, but fast, within the first $\sim 100 \mathrm{~h}$ under current and remained constant afterward (see the two curves in Fig. 4b, after 100 and 1500 h under current, which coincide). For the test carried out in synthetic air, the same characteristics (simultaneous increase of serial and polarization resistance; see Fig. 4c) as for the test in compressed air were observed, although to a smaller extent. That result is in good agreement with the observed smaller cell voltage degradation (see Fig. 2).

Hence, the observed changes in the impedance spectra of the cells under OCV before and after test (see above) are completely consistent with the impedance spectra recorded under current. Furthermore, the cathode degradation seems to be related to a simultaneous increase of serial as well as polarization resistance.

Microstructural analysis. - The aim of the microstructural analysis was to relate the differences in degradation behavior observed in air and oxygen to features on the cathode side. Therefore, the focus was set to the electrolyte/cathode interface. A convenient method to evaluate the contact area of LSM particles on the YSZ electrolyte is to remove the LSM and investigate the imprint of LSM
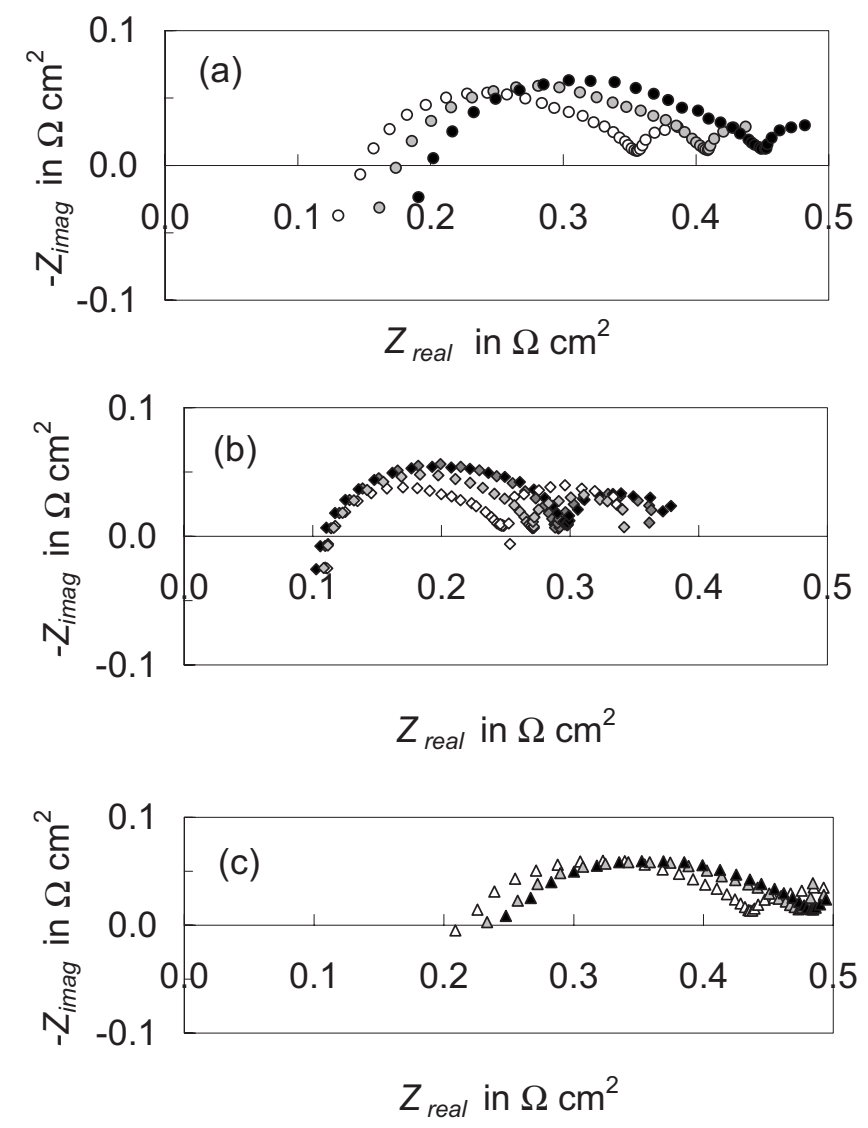

Figure 4. Impedance spectra recorded under current load at $750^{\circ} \mathrm{C}$, $0.75 \mathrm{~A} / \mathrm{cm}^{2}$. (a) Test in compressed air after 12 (white), 500 (gray), and 1000 (black) h under current, (b) test in oxygen after 13 (white), 50 (light gray), 100 (gray), and 1500 (black) h under current, and (c) test in synthetic air $\left(\mathrm{O}_{2} / \mathrm{N}_{2}=1 / 5\right)$ after 30 (white), 470 (gray), and 780 (black) h under current.

particles left on the electrolyte surface. By etching using $\mathrm{HCl}$, only LSM but not YSZ or zirconate phases are removed. In Fig. 5, the electrolyte surfaces of a reference cell and the two cells tested in air or oxygen over $1500 \mathrm{~h}$ at $750^{\circ} \mathrm{C}$ and $0.75 \mathrm{~A} / \mathrm{cm}^{2}$ are shown after etching away the cathode.

On the electrolyte of the not-tested reference cell (Fig. 5a), clear craters are visible, which represent contact regions of LSM particles on YSZ. Points left by YSZ appear as round protrusions. After testing in oxygen (Fig. 5b), the craters still appeared sharp, maybe even sharper. Noticeable differences in the morphology were observed on the cell after test in air.

In this case, a flattening of the crater rings and a reduction of their size occurred and nanosize particles were found in association with the craters (see Fig. 5c and d). The flattening of LSM crater rings and size reduction on the YSZ surface in the cell tested in air corresponds to a worsening or even loss of contact between the cathode (LSM) and electrolyte. In a previous study of the degradation as a function of temperature and polarization, a loss of contact regions after testing at $750^{\circ} \mathrm{C}$ and a high current load $\left(0.75 \mathrm{~A} / \mathrm{cm}^{2}\right)$, the same conditions as in this paper, was concluded from impedance analysis of the cells before and after testing and the examination of cross sections in the microscope. ${ }^{1}$ The findings in the microstructural analysis in this work support the conclusions drawn previously.

The nanoparticles, found in the cell after testing in air, may be an indication for chemical interactions between LSM and YSZ, for example the formation of lanthanum zirconate. They may also be impurity phases. The chemical composition of these particles cannot be determined directly as their size was too small for quantitative analysis by SEM/EDS. 

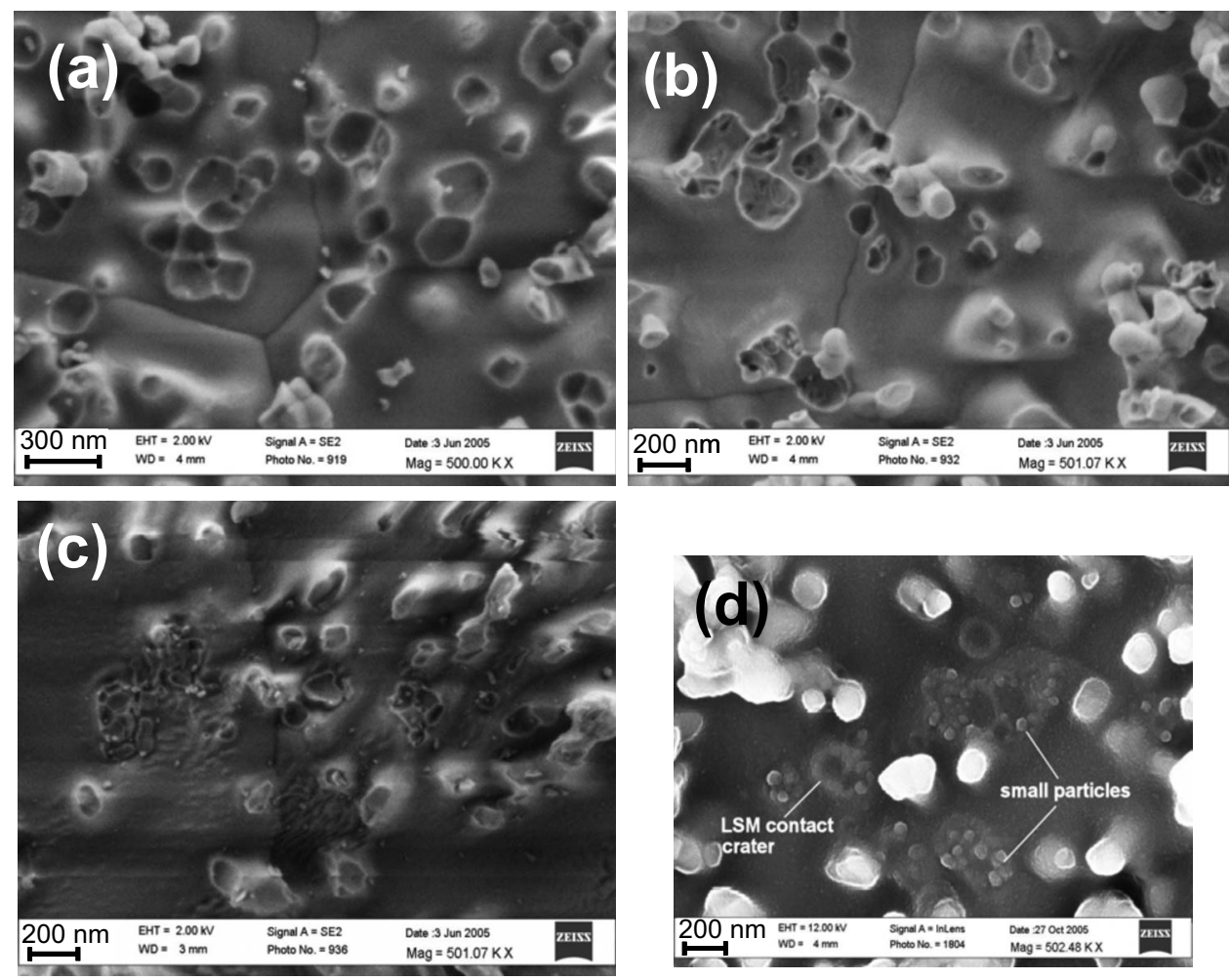

Figure 5. Electrolyte surface of cells after removal of the cathode (a) prior to testing $=$ reference cell, (b) after test in oxygen, or (c) and (d) air.

Also, a difference in the surface morphology of the electrolyte in areas surrounding LSM craters was observed. The electrolyte surface of the cell tested in air was rougher with more pronounced wrinkles as compared with the cell tested in oxygen (Fig. 5). The area with wrinkles stretched about $200 \mathrm{~nm}$ to $1 \mu \mathrm{m}$ from the crater.

In the EDS analysis (see Table III) no Sr was detected, which was taken as an indication for the complete removal of LSM. Focusing on the crater regions, the $\mathrm{Si}$ and $\mathrm{Mn}$ contents were higher than in the surrounding areas for all three cells. The La content was higher in the crater regions in two cells: the reference cell and in the cell tested in air, particularly in the latter. The Si level was lowest in the cell tested in oxygen.

The finding of extra La and $\mathrm{Si}$ in crater areas as compared to the surrounding regions in the reference cell and the cell tested in air is an indication of the presence of secondary phases, possibly LZO or silicate. The formation of LZO has been widely discussed (for example in Ref. 10-13). The conductivity of LZO is $2-3$ orders of magnitude lower than that of the zirconia electrolyte. ${ }^{14}$ The formation of LZO during operation of electrolyte-supported cells with LSM cathodes at $950^{\circ} \mathrm{C}$ and under cycling current load was also suggested to degrade mechanical adhesion at the cathode/electrolyte interface. ${ }^{10} \mathrm{La}$-silicate was reported to form at the $\mathrm{LaMnO}_{3} / \mathrm{YSZ}$ interface during aging at $14500^{\circ} \mathrm{C} .{ }^{15}$

Extra $\mathrm{Mn}$ in crater areas could be an indication of local dissolution of Mn from the LSM particles into the "sintering neck" of YSZ, which agrees with findings by Mitterdorfer and Gauckler, ${ }^{11}$ who reported Mn-doped YSZ crater rings with $\sim 7.4 \% \mathrm{Mn}$ (by EDS/ transmission electron microscopy) after sintering at $1100^{\circ} \mathrm{C}$.
The EDS results combined with the microstructural observations suggest the occurrence of local interfacial reactions between LSM and electrolyte to form LZO during testing at $750{ }^{\circ} \mathrm{C}$ (and maybe also during fabrication), in particular at lower $p_{\mathrm{O}_{2}}$ at the cathode side (air vs oxygen). There might be more silicate phase in the electrolyte/cathode interface region after testing in air. The presence of both LZO and silicate phases reduces the electrochemical activity at the three-phase boundary, weakens the LSM/electrolyte contact both electrically and mechanically, and may account for the different degradation behaviors in air and oxygen.

Our hypothesis about this degradation mechanism is schematically shown for a LSM particle in contact with the electrolyte surface in Fig. 6. Under conditions of low $p_{\mathrm{O}_{2}}$ at the cathode/electrolyte interface, an elemental redistribution occurs leading to a progressing separation of a LSM particle formerly firmly (crater!) attached to the electrolyte. At the same time, zirconate particles are formed at the points of detachments and manifest this separation. Two situations may occur: the LSM particle can either be completely removed or the contact area can become smaller as indicated in Fig. 6. The currently used technique to prepare samples for the microstructural analysis of the cathode/electrolyte interface does not permit differentiation between these two options.

The formation of LZO was proposed to be reversible, i.e., LZO formed at the LSM/YSZ interface during sintering of the cells might dissolve under polarization at $950^{\circ} \mathrm{C} .{ }^{16}$ Preliminary aging tests of cells at $1000^{\circ} \mathrm{C}$ in different gas atmospheres seemed to confirm this proposal. A reversibility of the phase reaction would open the very

\begin{tabular}{|c|c|c|c|c|c|c|}
\hline $\begin{array}{l}\text { Element } \\
\text { Location }\end{array}$ & $\begin{array}{c}\mathrm{La} \\
\text { Crater }\end{array}$ & $\begin{array}{c}\text { La } \\
\text { Surroundings }\end{array}$ & $\begin{array}{c}\mathrm{Si} \\
\text { Crater }\end{array}$ & $\begin{array}{c}\mathrm{Si} \\
\text { Surroundings }\end{array}$ & $\begin{array}{c}\text { Mn } \\
\text { Crater }\end{array}$ & $\begin{array}{c}\text { Mn } \\
\text { Surroundings }\end{array}$ \\
\hline Not-tested cell & +++ & + & +++ & + & ++++ & + \\
\hline Cell tested in oxygen & ++ & ++ & ++ & ++ & ++++ & ++ \\
\hline Cell tested in air & ++++ & + & ++++ & ++ & +++ & ++ \\
\hline
\end{tabular}




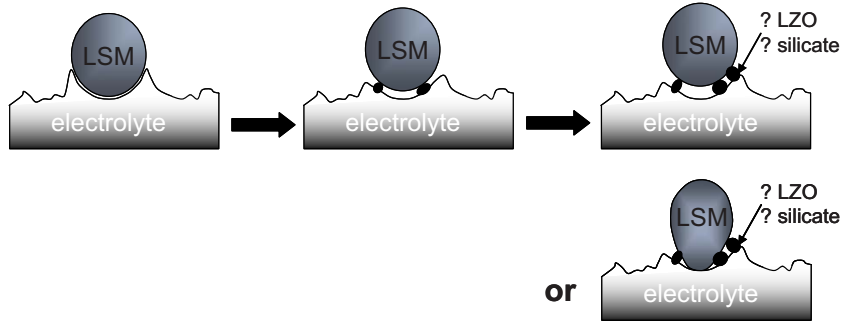

Figure 6. (Color online) Degradation of the cathode/electrolyte interface due to conditions of low $p_{\mathrm{O}_{2}}$ during testing.

attractive option for a regeneration of cells degraded at the cathode side according to the mechanism suggested above.

Therefore, a degraded cell was subjected to conditions of high $p_{\mathrm{O}_{2}}$ after $1500 \mathrm{~h}$ long-term testing at $750^{\circ} \mathrm{C}$ and $0.75 \mathrm{~A} / \mathrm{cm}^{2}$. The high $p_{\mathrm{O}_{2}}$ was chosen as the cells tested under such conditions did not show a pronounced LZO formation or probably even experienced a decomposition of LZO formed during sintering of the cells (see the previous discussion). The high $p_{\mathrm{O}_{2}}$ was achieved by setting the cell to $\mathrm{OCV}$ after the $1500 \mathrm{~h}$ aging period using air at the cathode side and furthermore also using oxygen instead to facilitate the regeneration. After a regeneration period of $500 \mathrm{~h}$, the cell was subjected to the same testing conditions as during the first $1500 \mathrm{~h}$. The cell voltage as a function of operating time and treatment is shown in Fig. 7.

The cell voltage degradation during the $1500 \mathrm{~h}$ aging was similar to the previous tests. The first regeneration period was accomplished in air for $\sim 500 \mathrm{~h}$ at OCV. Afterward, there was no significant recovery of the cell voltage when resuming the testing under current. The second regeneration period was performed in oxygen for $\sim 500 \mathrm{~h}$. Also after this treatment, the cell voltage did not recover significantly. The short activation observed after turning on the current for the first time also was repeated after the regeneration periods at OCV. However, the attempted regeneration treatment was not successful, also not at higher temperatures $\left(850^{\circ} \mathrm{C}\right.$, not shown here). The reasons for this "failure" could be because $(i)$ the removal of foreign phases does not proceed under the given conditions in the cell testing house (for example temperature range) and/or (ii) the phases are removed but the original microstructure is not reestablished.

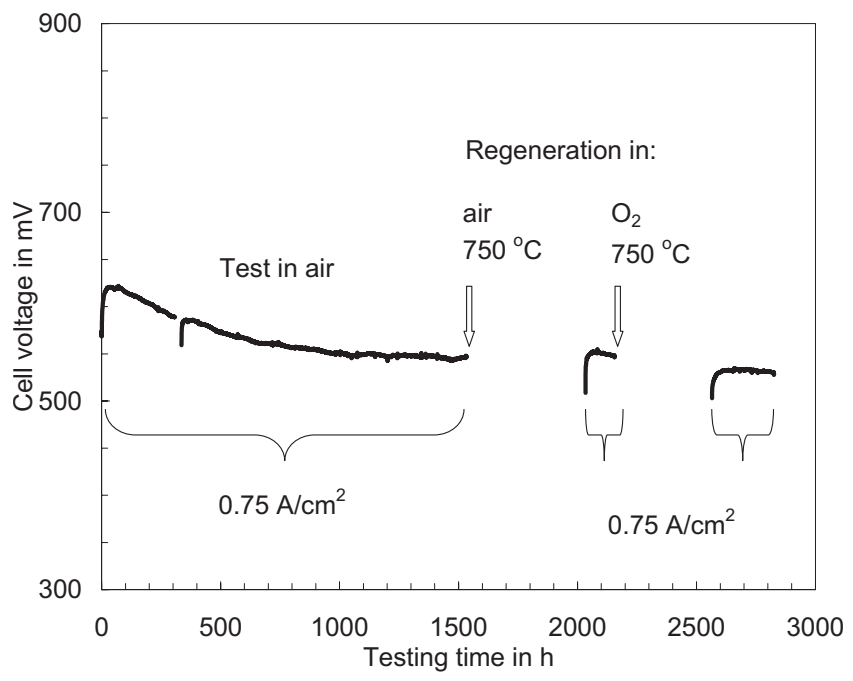

Figure 7. Cell voltage vs time under current for aging test in air at $750{ }^{\circ} \mathrm{C}$ and $0.75 \mathrm{~A} / \mathrm{cm}^{2}$, regeneration of the cell (1) in air at $\mathrm{OCV}$ and $750^{\circ} \mathrm{C}$, followed by test at $0.75 \mathrm{~A} / \mathrm{cm}^{2}$ and afterward (2) in oxygen at $\mathrm{OCV}$ and $750^{\circ} \mathrm{C}$, followed by another test period at $0.75 \mathrm{~A} / \mathrm{cm}^{2}$.

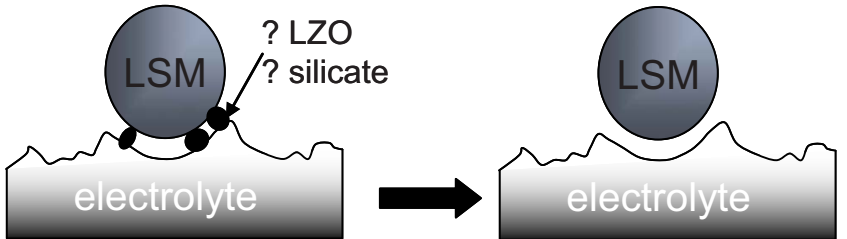

Figure 8. (Color online) Hypothesis of why attempted regeneration of cells at high $p_{\mathrm{O}_{2}}$ did not lead to recovery of initial performance.

The latter phenomenon is schematically explained in Fig. 8, in analogy to the degradation path scheme (see Fig. 6). When the zirconate (or other foreign phases) is removed, the geometric situation at the cathode/electrolyte interface does not necessarily change. Specifically, there is no sufficient driving (for example mechanical) force to close the gap or increase the contact area between a LSM particle and the electrolyte and thereby to re-establish the firm attachment (sharp crates) as in a fresh cell (Fig. 8).

However, although the regeneration did not give the desired results, the identification of the degradation path is very valuable to suggest a means of modifications of the LSM cathode/electrolyte interface to improve the durability.

\section{Conclusion}

The degradation behavior of anode-supported SOFCs was studied as a function of the cathode atmosphere and the polarization. The total degradation can be divided into at least two main processes, one initial, rather fast (within the first few hundred hours) that mainly proceeds at the anode, and a second continuous process occurring on the cathode. This latter degradation mechanism was found to be strongly dependent on the $p_{\mathrm{O}_{2}}$; it was almost suppressed when running the test in oxygen compared to air at the cathode side.

This suppression was also observed at high total cell and cathode polarization and therefore seems to be mainly caused by the change in oxygen activity in the interface region and elimination of oxygen concentration gradients when going to oxygen atmosphere, rather than being related to the reduction of cathode polarization in oxygen.

Microstructural examination of the cathode/electrolyte interface after removal of the cathode revealed craters as the contact areas of LSM on the electrolyte. These craters became more flat for the cells tested in air, whereas they appeared as sharp as initially after testing in oxygen. In addition, nanosized particles were found in conjunction with the craters after testing in air. It is suggested that the flattening and size reduction of the crater rings and the formation of secondary, less conducting or isolating phases (for example zirconate) in the LSM/electrolyte contact areas are the most important degradation mechanisms of the cathode. Direct identification of these nanosized phases requires more advanced techniques. In oxygen, these processes are suppressed to a large extent and therefore the cathode degradation can be diminished or even stopped. The observed microstructural and compositional changes are reflected in a simultaneous increase of the serial and polarization resistance of the cell.

\section{Acknowledgments}

The authors thank M. Davodi, H. Henriksen, O. Hansen, and S. Koch for technical assistance. The financial support by Energinet.dk, project PSO-Eltra-5849 and by the European Community, IP-project REAL-SOFC (SES6-CT-2003-502612), is gratefully acknowledged.

Ris $\phi$ National Laboratory assisted in meeting the publication costs of this article. 


\section{References}

1. A. Hagen, R. Barfod, P. V. Hendriksen, Yi. L. Liu, and S. Ramousse, J. Electrochem. Soc., 153, A1165 (2006)

2. R. Barfod, A. Hagen, S. Ramousse, and P. V. Hendriksen, in Solid State Electrochemistry. Proceedings. 26. Risø International Symposium on Materials Science, Ris $\phi(D K)$, 4-8 Sept. 2005, S. Linderoth, A. Smith, N. Bonanos, A. Hagen, L. Mikkelsen, K. Kammer Hansen, D. Lybye, P. V. Hendriksen, F. W. Poulsen, M. Mogensen, and W. G. Wang, Editors, Risø National Laboratory, Roskilde, p. 121 (2005).

3. A. Hagen, M. Menon, S. Ramousse, P. H. Larsen, R. Barfod, and P. V. Hendriksen, Fuel Cells, 6, 146 (2006).

4. J. G. Larsen, P. H. Larsen, and C. Bagger, U.S. Pat. 60/112039, Pending.

5. M. Mogensen and P. V. Hendriksen, in High Temperature Solid Oxide Fuel Cells, Fundamentals, Design, and Applications, S. C. Singhal and K. Kendall, Editors, Chap. 10, Elsevier, Amsterdo (2003).

6. R. Barfod, A. Hagen, S. Ramousse, P. V. Hendriksen, and M. Mogensen, Fuel Cells, 6, 141 (2006).

7. R. Barfod, M. Mogensen, T. Klemensoe, A. Hagen, Y. L. Liu, and P. V. Hendriksen, J. Electrochem. Soc., 154, B371 (2007).
8. X. J. Chen, K. A. Khor, and S. H. Chan, J. Power Sources, 123, 17 (2003).

9. M. J. Jørgensen and M. Mogensen, J. Electrochem. Soc., 148, A433 (2001)

10. M. J. Heneka and E. Ivers-Tiffee, in Solid State Electrochemistry. Proceedings. 26. Risø International Symposium on Materials Science, Ris $\phi(D K), 4-8$ Sept. 2005, S Linderoth, A. Smith, N. Bonanos, A. Hagen, L. Mikkelsen, K. Kammer Hansen, D. Lybye, P. V. Hendriksen, F. W. Poulsen, M. Mogensen, and W. G. Wang, Editors, Risø National Laboratory, Roskilde, p. 215 (2005).

11. A. Mitterdorfer and L. J. Gauckler, Solid State Ionics, 111, 185 (1998).

12. C. Clausen, C. Bagger, J. B. Bilde-Sørensen, and A. Horsewell, Solid State Ionics, 70-71, 59 (1994).

13. H. Y. Lee and S. M. Oh, Solid State Ionics, 90, 133 (1996).

14. J. A. Labrincha, J. R. Frade, and F. M. B. Marques, J. Mater. Sci., 28, 3809 (1993).

15. D. Kuscer, J. Holc, M. Hrovat, S. Bernik, Z. Samardzija, and D. Kolar, Solid State Ionics, 78, 79 (1995).

16. A. Weber, R. Männer, B. Jobst, H. Cerva, R. Waser, and E. Ivers-Tiffee, in High Temperature Electrochemistry: Ceramics and Metals. Proceedings. 17. Ris $\phi$ International Symposium on Materials Science, Ris $\phi$ (DK), 2-6 Sept. 1996, F. W. Poulsen, N. Bonanos, S. Linderoth, M. Mogensen, and B. Zachau-Christiansen, Editors, Risø National Laboratory, Roskilde, p. 473 (1996). 